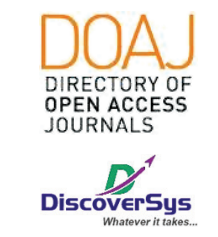

Published by DiscoverSys

\section{Implementasi lintas diare dan penggunaan obat antidiare pada anak dengan diare}

\author{
Vidya Lakshmi Anbhuselvam, ${ }^{1 *}$ I Putu Gede Karyana, ${ }^{2}$ Ni Putu Siadi Purniti ${ }^{3}$
}

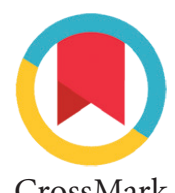

CrossMark

\title{
ABSTRACT
}

Introduction: Diarrhea is still a major problem that causes illness and death for children in Indonesia. Inappropriate care, both at home and in health agencies, is a major cause of deaths of children with diarrhea.

Method: The design of this study was descriptive with a cross sectional study design. The design of this study aims to be able to describe the implementation of cross diarrhea and the use of antidiarrheal drugs for pediatric patients with diarrhea at RSUP Sanglah Denpasar. The data used in the form of secondary data obtained from the medical records of Sanglah Hospital RSUP patients Denpasar January 2017-April 2017. The technique of determining the sample used is total sampling where all target populations that meet the criteria are included as samples.

Result: The most widely used cross group of diarrheas was ORS (Oral Rehydration solution) (17.9\%). The most commonly used antidiarrhea drug is adsorbent (11.6\%).

Conclusion: The most widely used cross-diarrhea group was ORS (Oral Rehydration solution) followed by the antibiotic group and so on the zinc group. There are minority cases that have given negative results on antibiotics. The most widely used group of antidiarrheal drugs was the adsorbent followed by the class of antimotility drugs and so on other classes of drugs such as probiotics and herbal medicines

Keywords: Nasal polyp, age, sex, major symptom, comorbidities, therapy Cite This Article: Anbhuselvam, V.L., Karyana, I.P.G., Purniti, N.P.S. 2019. Implementasi lintas diare dan penggunaan obat antidiare pada anak dengan diare. Intisari Sains Medis 10(3): 817-820. D0I: 10.15562/ism.v10i3.488

\section{ABSTRAK}

Latar Belakang: Diare masih menjadi masalah utama yang menyebabkan sakit dan kematian bagi anak-anak di Indonesia. Perawatan yang tidak tepat, baik dirumah maupun di instansi kesehatan, merupakan penyebab utama kematian anak-anak dengan diare.

Metode: Rancangan penelitian ini bersifat deskriptif dengan rancangan penelitian cross sectional. Rancangan penelitian ini bertujuan untuk dapat menggambarkan implementasi lintas diare dan penggunaan obat antidiare terhadap pasien anak dengan diare di RSUP Sanglah Denpasar. Data yang digunakan berupa data sekunder yang didapat dari rekam medis pasien Anak RSUP Sanglah Denpasar bulan Januari 2017-April 2017. Teknik penentuan sampel yang digunakan adalah total sampling dimana seluruh populasi target yang memenuhi kriteria dimasukan sebagai sampel.

Hasil: Golongan lintas diare paling banyak digunakan adalah cairan rehidrasi yaitu oralit sebanyak 34 (17,9\%). Penggunaan obat antidiare paling sering digunakan adalah adsorben sebanyak 22 (11,6\%).

Simpulan: Golongan lintas diare paling banyak digunakan adalah cairan rehidrasi yaitu oralit diikuti oleh golongan antibiotik dan seterusnya golongan zink. Terdapat kasus minoritas yang telah memberi hasil negatif pada pemberian antibiotik. Golongan penggunaan obat antidiare paling banyak digunakan adalah adsorben diikuti oleh golongan obat antimotilitas dan seterusnya golongan obat lain-lain seperti probiotik dan obat herbal
1Program Studi Pendidikan Dokter, Fakultas Kedokteran Universitas Udayana

${ }^{2}$ Departemen/SMF IImu Kesehatan Anak RSUP Sanglah, Fakultas Kedokteran Universitas Udayana

\section{*Korespondensi:}

Vidya Lakshmi Anbhuselvam, Program Studi Pendidikan Dokter, Fakultas Kedokteran Universitas Udayana

vidya764@gmail.com

Diterima: 06-04-2019

Disetujui: 21-11-2019

Diterbitkan: 01-12-2019

Kata kunci: anak-anak, diare, manajemen, lintas diare, penggunaan obat antidiare

Cite Pasal Ini: Anbhuselvam, V.L., Karyana, I.P.G., Purniti, N.P.S. 2019. Implementasi lintas diare dan penggunaan obat antidiare pada anak dengan diare. Intisari Sains Medis 10(3): 817-820. D0I: 10.15562/ism.v10i3.488

\section{PENDAHULUAN}

Diare akut adalah penyebab utama kedua kematian pada anak-anak di bawah lima tahun, dan bertanggung jawab terhadap meninggalnya sekitar 760000 anak setiap tahun. Diare akut dapat berlangsung beberapa hari, dan menyebabkan kehilangan air dan elektrolit yang diperlukan untuk kelangsungan hidup. Kebanyakan kematian pada diare disebabkan oleh dehidrasi berat. Anak-anak yang kekurangan gizi atau angka kematian yang tinggi disebabkan oleh tatalaksana diare di rumah dan tempat layanan kesehatan diare kurang tepat. ${ }^{1,2}$

Diare merupakan masalah kesehatan masyarakat terutama pada anak di bawah usia 5 tahun. Pada tahun 2002, diperkirakan 1.6 juta anak-anak, meninggal akibat diare di negara berkembang. Diare adalah pembunuh utama selain 
penyakit seperti ISPA, Campak dan infeksi lainnya. Upaya internasional dan nasional untuk mengatasi masalah diare bertujuan untuk mengurangi morbiditas diare dan kematian. ${ }^{3}$

Menurut World Health Organization (WHO), penyakit diare adalah suatu penyakit yang ditandai dengan perubahan bentuk dan konsistensi tinja yang lembek sampai mencair dan bertambahnya frekuensi buang air besar yang lebih dari biasa, yaitu 3 kali atau lebih dalam sehari yang mungkin dapat disertai dengan muntah atau tinja yang berdarah. Penyakit ini paling sering dijumpai pada anak balita, terutama pada 3 tahun pertama kehidupan, dimana seorang anak bisa mengalami 1-3 episode diare berat. ${ }^{4}$

Diare sangat umum di Indonesia karena kontrol kesehatan masyarakat yang tidak efektif dan standar kebersihan yang buruk. Penularan diare pada umumnya bersumber dari makanan atau minuman yang mengandung patogen penyebab diare. Penyebab diare pada umumnya disebabkan oleh bakteria dan parasit. Gejala utama diare adalah mual, muntah, dan sakit perut. Muntah biasanya reda dalam satu atau dua hari. Diare dapat berlangsung hingga 10 hari, tetapi biasanya berlangsung selama dua atau tiga hari.

Kematian akibat diare akut biasanya bukan karena adanya infeksi dari bakteri atau virus, tetapi karena terjadi dehidrasi. Pada diare yang hebat anak akan mengalami buang air besar dalam bentuk cair beberapa kali dalam sehari dan sering disertai dengan muntah, panas, bahkan kejang. Oleh karena itu, tubuh akan kehilangan banyak air dan garam-garam, sehingga dapat mengakibatkan dehidrasi, asidosis, hipoglikemis, yang tidak jarang akan berakhir dengan shock dan kematian. Pada bayi dan anak-anak kondisi ini lebih berbahaya karena cadangan intrasel dalam tubuh mereka kecil dan cairan ekstra selnya lebih mudah dilepaskan jika dibandingkan oleh orang dewasa. ${ }^{5}$ Penggunaan obat pada diare akan lebih baik dan bermanfaat, jika benar-benar memenuhi kriteria rasionalnya. Proses pemilihannya dilakukan secara konsisten mengikuti standar baku akan menghasilkan penggunaan obat yang optimal. ${ }^{6}$

Pada tahun 2005, pedoman penatalaksanaan diare terbaru dikeluarkan oleh World Health Organization.. ${ }^{4}$ Departemen Kesehatan Republik Indonesia (Depkes RI) telah mengeluarkan panduan tatalaksana diare yang dikenal dengan Lintas Diare (Lima Langkah Tuntaskan Diare) yang terdiri dari: rehidrasi, nutrisi, suplementasi zink, pemberian antibiotik yang selektif dan edukasi orang tua. Walaupun panduan tatalaksana diare sudah ada, namun implementasi di lapangan masih belum sesuai, bahkan kerap obat antidiare digunakan oleh dokter dan tenaga medis lainnya.

\section{METODE}

Penelitian ini merupakan penelitian deskriptif dengan desain cross-sectional untuk untuk dapat menggambarkan implementasi lintas diare dan penggunaan obat antidiare terhadap pasien anak dengan diare di RSUP Sanglah Denpasar. Penelitian ini dilakukan di Poliklinik Anak, Instalasi Gawat Darurat (IGD), dan Rawat Inap Rumah Sakit Umum Pusat Sanglah Denpasar pada bulan Juli 2018 - Nopember 2018.

Sampel pada penelitian ini adalah pasien anak dengan diare yg mengunjungi Poliklinik Anak, Instalasi Gawat Darurat (IGD), dan Rawat Inap Rumah Sakit Umum Pusat Sanglah pada Januari 2017-April 2017. Kriteria inklusi adalah pasien dengan diare akut berusia 6 bulan - 5 tahun. Kriteria eksklusi adalah Rakam medis tidak lengkap dan pasien diare akut dengan penyakit penyerta. 190 sampel penelitian yang memenuhi kriteria diikutsertakan dalam penelitian ini.

Pengumpulan data dilakukan dengan menggunakan data sekunder, Data yang diambil berasal dari rekam medis bulan Januari 2017-April 2017. Pengumpulan data secara retrospektif dari rekam medik pasien diare di Rumah Sakit Umum Pusat Sanglah Denpasar dengan menggunakan teknik purposive sampling. Data yang dicatat meliputi: nomor rekam medik, diagnosis, umur, berat badan dan nama obat. Anak-anak dengan diare dijabarkan dalam kelompok berusia 6 bulan-1 tahun, 1-3 tahun dan 3-5 tahun. Jenis kelamin termasuk perempuan dan laki-laki. Data yang telah diperoleh sesuai dengan karakteristik sampel yang teliti disajikan secara deskriptif. Kemudian, dilakukan perhitungan hasil pengambilan data dalam bentuk tabel dan narasi.

\section{HASIL}

Kejadian diare pada balita berdasarkan usia balita enam bulan hingga satu tahun sebanyak 56 anak $(29,4 \%)$ termasuk laki-laki dan perempuan, usia satu tahun hingga tiga tahun sebanyak 64 orang $(33,8 \%)$ dan pada usia tiga tahun hingga lima tahun sebanyak 70 orang $(36,8 \%)$. Data tersebut menunjukkan bahwa kejadian diare pada balita berdasarkan jenis kelamin perempuan sebanyak 76 orang (40\%) dan laki-laki sebanyak 114 orang (60\%) (Tabel 1).

Golongan lintas diare paling banyak digunakan adalah cairan rehidrasi yaitu oralit sebanyak $34(17,9 \%)$. Golongan obat zink digunakan sebanyak 21 (11\%) serta golongan antibiotik dijabarkan menjadi sesuai dengan indikasi dan tidak sesuai dengan indikasi yang berjumlah 10 (5,3\%). Golongan obat oralit dan zink digunakan sebanyak $31(16,3 \%)$. Golongan obat oralit dan antibiotik 
Tabel 1 Karakteristik subjek kejadian diare pada anak berdasarkan jenis kelamin dan usia di RSUP Sanglah

\begin{tabular}{lcccc}
\hline Jenis Kelamin & Usia & N & \% & Jumlah \\
\hline Laki-Laki & 6 bulan-1 tahun & 35 & 18.4 & \\
& 1 tahun-3 tahun & 47 & 24.8 & \multirow{2}{*}{$114(60 \%)$} \\
\multirow{3}{*}{ Perempuan } & 3 tahun-5 tahun & 32 & 16.8 & \\
& 6 bulan-1 tahun & 21 & 11.0 & \\
& 1 tahun-3 tahun & 17 & 9.0 & $76(40 \%)$ \\
& 3 tahun-5 tahun & 38 & 20.0 & \\
\hline
\end{tabular}

Tabel 2 Jenis lintas diare yang digunakan pada anak diare di RSUP Sanglah

\begin{tabular}{lcc}
\hline Lintas Diare & N: $\mathbf{1 2 6}$ & \%: 66,3 \\
\hline Oralit & 34 & 17.9 \\
Zink & 21 & 11.0 \\
Antibiotik: & & \\
R & 7 & 3.70 \\
NR & 3 & 1.60 \\
Oralit + Zink & 31 & 16.3 \\
Oralit + Antibiotik & 19 & 10.0 \\
Zink + Antibiotik & 0 & 0.00 \\
Oralit + Zink + Antibiotik & 11 & 5.80 \\
\hline
\end{tabular}

R: Sesuai dengan indikasi

NR: Tidak sesuai dengan indikasi

Tabel 3 Jenis penggunaan obat antidiare yang digunakan pada anak diare di RSUP Sanglah

\begin{tabular}{lcc}
\hline Penggunaan Obat Antidiare & N: $\mathbf{6 4}$ & \%: $\mathbf{3 3 , 7}$ \\
\hline Adsorben & 22 & 11.6 \\
Antimotilitas & 21 & 11.1 \\
Probiotik & 16 & 8.40 \\
Obat herbal & 5 & 2.60 \\
\hline
\end{tabular}

digunakan sebanyak 19 pasien (10\%). Golongan obat oralit, zink dan antibiotik digunakan sejumlah $11(5,8 \%)$ (Tabel 2).

Penggunaan obat antidiare paling sering digunakan adalah adsorben sebanyak 22 (11,6\%). Golongan obat antimotilitas digunakan sebanyak $21(11,1 \%)$. Golongan obat probiotik digunakan sebanyak $16(8,4 \%)$ serta golongan obat herbal digunakan sebanyak 5 (2,6\%). Penggunaan obat antidiare yang digunakan selain probiotik adalah $48(25,3 \%)$ (Tabel 3).

\section{DISKUSI}

Berdasarkan data tabel 1, kejadian diare pada anak balita berdasarkan jenis kelamin mayoritas terjadi pada laki-laki sebanyak 114 orang (60\%), dan minoritas terjadi pada anak perempuan sebanyak
76 orang (40\%). Berdasarkan Hamdani (2001) menyatakan ada hubungan yang bermakna antara jenis kelamin dengan kejadian diare pada balita. Jenis kelamin dapat mempengaruhi kejadian diare, balita dengan kelamin laki-laki lebih sering terkena diare daripada balita berkelamin perempuan. Dari penelitian yang dilakukan jenis kelamin berpengaruh terhadap kejadian diare yang di dapat mayoritas kejadian diare pada balita laki-laki karena laki-laki lebih berani kotor dan lebih aktif berbanding dengan balita perempuan yang lebih suka main di rumah dan bermain dengan boneka dibanding main kotor-kotoran. ${ }^{7}$

Kejadian diare pada anak balita berdasarkan usia balita mayoritas terjadi pada usia 3-5 tahun sebanyak 70 anak $(36,8 \%)$ diikuti oleh usia 1-3 tahun sebanyak 64 orang $(33,8 \%)$ dan minoritas terjadi pada usia 6 bulan-1 tahun sebanyak 56 orang (29,4\%) (Tabel 1). Menurut Badriul Hegar Ketua Ikatan Dokter Anak Indonesia (IDAI) dalam bukunya pedoman pelayanan medis Ikatan Dokter Anak Indonesia jilid 1. Jakarta (2011), anak-anak atau balita lebih rentan terkena diare karena daya tahan tubuhnya masih rendah dibandingkan orang dewasa. Diare bisa disebabkan oleh infeksi bakteri maupun virus di dalam usus halus. Gejalanya biasanya disertai mual, demam, sakit perut dan dehidrasi. Namun jika menemui diare berat pada bayi yang berusia di bawah 5 tahun, hal itu tak perlu dikhawatirkan. Anak berusia 1 bulan hingga 5 tahun sering mengalami diare 8-10 kali sehari. Hal ini wajar karena enzim laktase dalam usus bayi belum berkembang baik sehingga laktosa dalam susu tidak dapat dipecah dan justru menarik cairan di usus. Dari penelitian yang dilakukan usia berpengaruh terhadap terjadinya diare karena balita yang lebih dari 5 tahun dapat mengerti apa yang orang tua ajarkan contohnya seperti cuci tangan sebelum makan dan sesudah makan, kekebalan tubuhnya juga lebih kuat dibanding umur dibawah 5 tahun, sehinga diare pada usia di atas 5 tahun sedikit untuk terjadi diare. ${ }^{6}$

Golongan lintas diare paling banyak digunakan adalah cairan rehidrasi yaitu oralit sebanyak 34 pasien (17,9\%). Golongan obat zink digunakan sebanyak 21 pasien $(11.0 \%)$ serta golongan antibiotik sebanyak 10 pasien (5,3\%). Sedangkan pada diagnosa pasien diare terdapat 3 kasus yang telah beri antibiotik hasil negative (Tabel 2). Dari hasil tersebut dapat dikatakan bahwa manajemen pengobatan di RSUP Sanglah belum tercapai dengan baik. Hal ini dapat berpengaruh dalam peningkatan mutu pelayanan kesehatan di RSUP Sanglah Penggunaan antibiotik yang tidak tepat akan menyebabkan bakteri menjadi resisten terhadap pemberian antibiotik, sehingga pada akhirnya suatu saat nanti antibiotik tidak dapat mengatasi infeksi yang 
disebabkan oleh bakteri. ${ }^{8}$ Pada tatalakana terapi diare pada anak menurut Depkes (2011) yang tertulis di buku Lintas Diare (Lima Langkah Tuntaskan Diare) yang terdiri dari oralit, zink, pemberian ASI atau makanan, pemberian antibiotik atas indikasi dan pemberian nasihat. Tatalaksana terapi diare ini bertujuan untuk mencegah dan mengobati dehidrasi, memperpendek lamanya sakit dan mencegah diare menjadi berat. ${ }^{9}$

Golongan penggunaan obat antidiare paling banyak digunakan adalah adsorben sebanyak $22(11,6 \%)$ diikuti oleh golongan obat antimotilitas digunakan sebanyak 21 (11,1\%). Golongan obat probiotik digunakan sebanyak $16(8,4 \%)$ serta golongan obat herbal digunakan sebanyak $5(2,6 \%)$. Penggunaan obat antidiare yang digunakan selain probiotik adalah $48(25,3 \%)$ (Tabel 3). Obat-obat antimotilitas memiliki peranan dalam penanganan diare akut tanpa komplikasi pada pasien dewasa tapi tidak pada anak-anak di bawah 12 tahun. Obat diare yang beredar adalah sejenis absorben dan antimotilitas yang mempunyai efek menghambat atau memperlambat pergerakan usus. Obat antimotilitas yang beredar di pasaran adalah loperamide dan salah satu dari efek samping loperamide adalah terjadinya paralitik ileus. Loperamide menghentikan diare dengan mengurangi aktivitas sirkular dan longitudinal dari usus. Loperamide memperlambat pergerakan di usus dan meningkatkan waktu kontak sehingga menghambat sekresi cairan dan elektrolit. ${ }^{6}$

\section{SIMPULAN}

Dari hasil penelitian ini Kejadian diare pada anak berdaskan jenisnya mayoritas terjadi pada laki-laki dibandingkan dengan anak perempuan. Kejadian diare pada anak yang paling banyak terjadi pada usia tiga tahun hingga lima tahun diikuti oleh usia satu tahun hingga tiga tahun dan seterusnya usia balita enam bulan hingga satu tahun. Golongan lintas diare paling banyak digunakan adalah cairan rehidrasi yaitu oralit diikuti oleh golongan antibiotik dan seterusnya golongan zink. Terdapat kasus minoritas yang telah memberi hasil negatif pada pemberian antibiotik. Golongan penggunaan obat antidiare paling banyak digunakan adalah adsorben diikuti oleh golongan obat antimotilitas dan seterusnya golongan obat lain-lain seperti probiotik dan obat herbal. Terdapat kasus minoritas memberi hasil negatif pada pemberian obat adsorben dan obat antimotilitas.

\section{KONFLIK KEPENTINGAN}

Penulis menyatakan tidak terdapat suatu konflik kepentingan terhadap publikasi dari artikel ini.

\section{PENDANAAN}

Penelitian ini tidak mendapatkan suatu pendanaan yang diberikan oleh pemerintah ataupun lembaga swasta lainnya.

\section{KONTRIBUSI PENULIS}

Konsep penelitian: Vidya Lakshmi Anbhuselvam, I Putu Gede Karyana, Ni Putu Siadi Purniti. Pengumpulan data, input data dan pengolahan data: Vidya Lakshmi Anbhuselvam. Penyusunan naskah Penelitian: Vidya Lakshmi Anbhuselvam.

\section{ETHICAL CLEARANCE NUMBER}

\section{2/UN14.2.2/PD/KEP/2018.}

\section{DAFTAR PUSTAKA}

1. World Gastroenterology Organisation. Acute Diarrhea in Adults and Children: A Global Perspective. 2012.

2. Grandinata Soeseno W., Bikin Suryawan I., Suarca K. Hubungan antara derajat dehidrasi dengan penurunan berat badan pada anak diare usia 1 sampai 5 tahun di ruangan kaswari dan poliklinik anak RSUD Wangaya kota Denpasar. Intisari Sains Medi. 2019. 10(1). DOI: 10.15562/ ism.v10i1.322

3. Nuraini, R. Morbiditas dan Mortalitas Diare pada Balita di Indonesia, Tahun 2000-2007. Kementerian Kesehatan RI. Jakarta. 2012.

4. WHO. The Treatment of Diarrhea in Preventing Infantile Diarrhea in the Developing World. Curr Tropp Med Rep. 2016. 1: 97-105.

5. Kligler B., Cohrssen A. Harmful practices in the management of childhood diarrhea in low- and middle-income countries: a systematic review. Serbia. 2016. 143:755-762.

6. Ikatan Dokter Anak Indonesia (IDAI). Kumpulan Tips Pediatrik. Jakarta: Badan Penerbit Ikatan Dokter Anak Indonesia. 2011.

7. Hamdani. Strategi Belajar Mengajar, Bandung: CV Pustaka Setia. 2011.

8. Faure C. Role of Antidiarrhoeal Drugs as Adjunctive Therapies for Acute Diarrhoea in Children. International Journal of Pediatrics. 2013. pp.1-14.

9. Departemen Kesehatan RI. Panduan Sosialisasi Tatalaksana Diare Pada Balita, Jakarta, Kementerian Kesehatan Republik Indonesia Direktorat Jenderal pengendalian Penyakit dan Penyehatan Lingkungan. 2011.

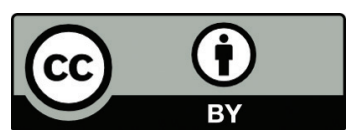

This work is licensed under a Creative Commons Attribution 